\title{
The Deficiencies and Features of Forensic Identification in China
}

\author{
Fangming Song*1 and Jia Wei ${ }^{2}$ \\ ${ }^{1}$ Law School, Shanxi University of Finance and Economics, China \\ ${ }^{2}$ Institute of American Studies, Chinese Academy of Social Science, China
}

Submission: November 17, 2017; Published: November 22, 2017

*Corresponding author: Fangming Song, Shanxi University of Finance and Economics, 696 of Wucheng Road, Xiaodian District, Taiyuan, China, Email: sfm7863@163.com

\section{Short Communication}

\section{The Deficiencies of Forensic Identification in China}

By introducing united supervision, Document No. 21 of Central Committee of the Communist Party of China put forward the new command on promoting the reform in forensic identification and evaluation system in 2004. Further, Decision of the Standing Committee of the National People's Congress on the Administration of Forensic Identification and Evaluation (2015 Amendment) (The Decision) stated the abolishment of division of forensic identification and evaluation in People's Courts and authority of justice administrative department on carrying out the registration administration towards Forensic Identification Institutions. Crucially, though, it failed to integrate the forensic identification experts and institutions, which provides free service to the police investigation, under the police system.

In the year of 2005, Ministry of Public Security issued Measures for Registration by on Forensic Identification Experts by Public Security Organs and Measures for Registration by on Forensic Identification Institutions by Public Security Organs, both of which forbid forensic identification experts and divisions of police register at any justice administrative department but shall at the police system in need of separated regulation. What's more, other investigation authorities, including procuratorate in charge of investigation on duty crimes and State Security Department carrying on investigation to crimes endangering national security, followed the routine of police system on organizing respective forensic experts and divisions. Eventually, the separated registered and regulated forensic identification institutions set by investigation authorities and the ones serve the personal demand compose the "twin-track" system of forensic identification and evaluation in China.

However, forensic identification institutions set by investigation authorities, for the past decade, has been drawing controversy due to the absence of supervision onto registration and its lack of independence in administrative hierarchy as well as in criminal proceedings. As a respond to the clamour for reform, the Fourth Plenary Session of the 18th CPC Central Committee, convened in October 2014, promulgated Decision on Several Major Issues concerning Governing the Country under the Rule of Law which mandated the integration of the double tracks of forensic identification.

\section{Status Quo of Forensic Identification in China}

Due to the aforementioned separation on registration and supervision, statistics on forensic identification institutions serve an investigation authority, which isn't accessible to the public, in China is confidential. Therefore, we managed to collect the data on the second track- forensic identification institutions, registered and supervised by justice administrative departments, which have played an active role in the private party involved suits. Up to the end of 2016 , there are 4,872 forensicidentification institutions $1.06 \%$ less than the year before, registered in the database of justice administrative departments over China. The amount of forensic identification experts, consequently, has slightly dropped by $2.63 \%$ in the same year. 2,131,578 cases of forensic identification and evaluation, increased by $2.06 \%$ over the year 2015, have brought in 3,669billion RMB receipts in total with an annual growth of $17.94 \%$.

2,582 forensic identification institutions, $53 \%$ out of 4,872 open to the public, are qualified to practice identification and evaluation on autopsy, physical evidence, audio-visual materials and environmental damage. Among the ones who are licensed to practice autopsy, $41.19 \%$ provide clinical forensic identification service, $15.02 \%$ take up pathological forensic identification, $9.52 \%$ engage in toxicological forensic identification, $7.98 \%$ run material evidence identification and $4.97 \%$ focus themselves on psychiatric forensic identification. 2,290 account 47\%, cover the identification and evaluation in the field of intellectual property, judicial audit, construction projects as well as product quality and price, among which, $22.33 \%$ are judicial audit institutions and $19.64 \%$ are construction project identification institutions. 
35. $92 \%$ of the forensic identification institutions are public ones funded by health, education and scientific research departments of the government, which means the rest are run by enterprises. The ones who practice identification and evaluation on autopsy, physical evidence, audio-visual materials and environmental damage, as the major services provided, $64.41 \%$ are operated by public organizations. As for the ones who devoted themselves into other occasional identification, on the contrary, only $3.8 \%$ of which are owned by the state. Take a glance at the qualifications of the forensic identification institutions, 464 , account for $9.52 \%$, have licenses for operating more than 5 types of forensic identification and evaluation, which has drawn a growth of $5.7 \%$ than the year 2015. There are 57.29 , more than half of which, are qualified with one single of forensic identification business.

As regards the amount of forensic identification experts, 593 forensic identification institutions, taking up $12.17 \%$, have hired more than 20 professional employees. One of third, 1,489 institutions, have a team of 5 or less professional members. In terms of the ages of the professional members on the forensic identification teams, most of them are aged between 31 to $50(54.17 \%)$ and 50 to 60 (30.08\%). 2,336 of the forensic identification experts have a PhD., 5,768 own mater degree, 33,858 graduated with a bachelor degree, and the rest, 12,711 employees are graduates from vocational colleges. In total, more than $77.42 \%$ of the experts are with bachelor degrees or above, which is an increase of $0.25 \%$ over the year 2015 .

Table 1: Classification on forensic identification institutions.

\begin{tabular}{|c|c|}
\hline Assigned by & Proportion \\
\hline Courts, Procuratorates and Police & $59.81 \%$ \\
\hline Law firms & $5.91 \%$ \\
\hline Enterprises \& public institutions & $4.20 \%$ \\
\hline Individuals & $27.98 \%$ \\
\hline other & $2.09 \%$ \\
\hline
\end{tabular}

Table 2: Classification on forensic identification cases.

\begin{tabular}{|c|c|}
\hline Types of cases & Proportion \\
\hline Criminal case & $14.92 \%$ \\
\hline Civil case & $43.25 \%$ \\
\hline Administrative case & $0.90 \%$ \\
\hline Non-litigation practice & $40.92 \%$ \\
\hline
\end{tabular}

Over all, forensic identification institutions registered at justice administrative departments, by the end of 2016, have finished 2,131,578 cases with total receipts of 3.669 billion. With a leap of $62.8 \%, 24,185$ cases were provided legal aid, which drives a bill of 70.3425 million RMB paid by Chinese government. Top 4 major practices, known as identification and evaluation on autopsy, physical evidence, audio-visual materials and environmental damage, constitute $89.57 \%$ of the whole forensic identification business, among which, $81.89 \%$ of the cases required autopsy. $59.81 \%$ of the cases of forensic identification and evaluation are assigned by courts, Procuratorates and police (Table 1). By the year 2016, $43.25 \%$ of the cases involved forensic identification and evaluations are civil ones, ranking top among all types of cases (Table 2). The statistics are as followed (Tables 1 \& 2)

\section{Conclusion}

Given the fast pace of criminal investigation and the rigid hierarchy between administrative divisions, integrating forensic identification institutions or divisions set by investigation authorities, who provide free and efficient service, with other forensic identification institutions open to the public, seems out of the question by far. The justice administrative departments, in need of efficiency and independence, it's about time to switch the method and policy on management, focusing on administrative supervision and service instead of administrative penalty and registration.

Funding: This research received a 2017 Foundation of Shanxi Law Society Grant for Integrating Mechanism on Management and Application of Forensic Identification [fund no. SXLS(2017)B08]. The project is led by Dr. Song Fangming"

\section{Your next submission with Juniper Publishers} will reach you the below assets

- Quality Editorial service

- Swift Peer Review

- Reprints availability

- E-prints Service

- Manuscript Podcast for convenient understanding

- Global attainment for your research

- Manuscript accessibility in different formats

( Pdf, E-pub, Full Text, Audio)

- Unceasing customer service

Track the below URL for one-step submission https://juniperpublishers.com/online-submission.php 